\title{
Geomorphology and Hydrology of the Benin Region, Edo State, Nigeria
}

\author{
Catherine Imhangulaya Ikhile \\ Department of Geography and Regional Planning, Faculty of Social Sciences, University of Benin, Benin City, \\ Nigeria \\ Email: ikhilek@yahoo.com
}

Received 27 December 2015; accepted 23 February 2016; published 26 February 2016

Copyright (C) 2016 by author and Scientific Research Publishing Inc.

This work is licensed under the Creative Commons Attribution International License (CC BY).

http://creativecommons.org/licenses/by/4.0/

(c) () D Open Access

\section{Abstract}

This paper examines the geomorphology and hydrology of the Benin Region, Edo State, Nigeria. The major landform features and processes of the region are highlighted. This region is a strategic and significant landscape in Nigeria. Information was gathered on the various aspects of the landscape, including the Geology, Physiography (Relief) and Geomorphology, Geomorphic processes, Weathering, Drainage processes, Landforms, Surface Water Hydrology and Water Resources. The Benin Region is underlained by sedimentary formation of the South Sedimentary Basin. The geology is generally marked by top reddish earth, composed of ferruginized or literalized clay sand. Geologically, the Benin Region comprises of 1) the Benin formation; 2) alluvium; 3) drift/top soil and 4) Azagba-Ogwashi (Asuba-Ogwashi) formation. Several parts of the region are surrounded by the Benin historical moats. The region has been described as a tilled plain in the south western direction. The local relief of the region is $91 \mathrm{~m}$. Boreholes records in the Benin Region show evidence of deep chemical weathering overtime. Soil profile reveals that the region is composed mainly of reddish brown sandy laterite. Intermittent layers of porous sands of sandy clays may reach a large depth as found in the borehole drilled in the region. These are products of deep chemical decay of the original parent rock materials. Three river systems drain the Benin Region. They are the Ikpoba River, the Ogba River and Owigie-Ogbovben River systems. The mean annual discharge of Ikpoba River for 1982-1983 and 1993-2002 was $1411 \mathrm{~mm} / \mathrm{yr}$, which was $1.019 \times 10^{9}$ $\mathrm{m}^{3}$ with a mean annual baseflow of $1256.23 \mathrm{~mm}\left(0.907 \times 109 \mathrm{~m}^{3}\right)$. This constitutes $87.65 \%$ of the total flow. It has a mean annual surface runoff of $225.18 \mathrm{~mm}\left(0.112 \times 10^{9} \mathrm{~m}^{3}\right)$ or $24.4 \%$ of the total discharge. The water resources of the region include surface water and underground water.

\section{Keywords}

Geology, Physiography (Relief) and Geomorphology, Geomorphic Processes, Weathering, Drainage Processes, Landforms, Surface Water Hydrology and Water Resources 


\section{Introduction}

\subsection{General Introduction}

The physical characteristics of the Benin Region which are relevant for the purpose of this investigation are hereby discussed in terms of those factors which [1]-[3] identified as the environment of weathering. They include the geological foundation and rock types, types and density of plant cover, availability of readily weatherable rocks, and tropical humid climate with seasonality of rainfall or alternating wet and dry seasons and topography amongst others. The geology and geomorphologic processes and landforms of the Benin Region have their interplay/interconnections with weathering. In a broad term, the geomorphology includes aspects of the geology and relief while the hydrology embraces aspects of the drainage and water resources. These are discussed below under the following headings: Geology, Physiography (Relief) and Geomorphology, Geomorphic Processes, Weathering, Drainage Processes, Landforms, Surface Water Hydrology and Water Resources. These aspects have not been fully documented by research workers in this region. This paper therefore examines these aspects as they affect the landscape of the region.

\subsection{Geology}

The Benin Region is underlain by sedimentary formation of the South Sedimentary Basin. The geology is generally marked by top reddish earth, composed of ferruginized or literalized clay sand. [4] first used the term Benin sand to describe the reddish earth underlain by sands, sandy clays and ferruginized sandstone that mark the Paleo-Coastal Environment of Paleocene-Pleistocene Age. These sediments spread across the southern fringes of the Anambra Basin and marking the upper fancies off-flaps of the Niger Delta. [5] used the name Coastal plain sands to describe the formation of red earth underlain by sands and clays that mark an ancient coastal plain environment now exposed in Calabar, Owerri, Onitsha and the Benin Region with the age Oligocene-Pleistocene.

However [6] reinstated the name Benin formation to identify the reddish-brown-yellow generally white sands often with clayey and pebbly horizons with type-locality around Benin. This is also referenced at Calabar and other parts of South Eastern Nigeria. The formation was further established by well logging of Etete 1, well drilled on-shore east of River Niger by Shell Nigeria. Petroleum Development Company (SPDC) and described by [7]. The formation is about $1830 \mathrm{~m}$ thick at the seashore but thins landwards. The sedimentary suits of the Benin Formation dip $2^{\circ}-8^{\circ}$ south (Figure 1). Geologically, the Benin Region comprises of 1 ) the Benin formation; 2) alluvium; 3) drift/top soil and 4) Azagba-Ogwashi (Asuba-Ogwashi) formation.

\subsubsection{The Benin Formation}

It is assigned to the Oligocene-Pleistocene period in the continent of Africa and to the Oligocene-Pleistocene recent at the sub-oceanic [7] [8]. The formation is characterized by top reddish to reddish brown lateritic massive fairly indurate clay and sand. This is often marked with reticulate muderacks. This caps the underlying more friable pinkish-yellowish white often gravelly-pebble sands clayey soils, sands and clay [9]. The sedimentary sequences are poorly bedded with discontinuous clay horizons at various depths. It is estimated to be about $800 \mathrm{~m}$ thick under Benin City and about 1,830m near the sea shore sections of the formation. They are exposed at various erosion sites, sand quarry sites, and road cuttings. The Benin formation covers $95 \%$ of the region.

\subsubsection{Alluvium}

These are found along Ikpoba and Ovia flood plains. They are made up of grayish-dirty white-yellowish-white sands, silts, clayey sands, gravels and even wood-plant materials. These have been washed down the river valley and deposited at the river banks. They are recent deposits.

\subsubsection{Drift/Top Soil}

Drifts are sediments still in the process of transportation or movement. They are made up of light brown-yellowish silt, mudflows and sands derived from the weathering of the parental Benin Formation. Drifts are washed down by fluvial agents especially the storms and floods dominating the wet season of the region. The drifts are not part of the solid geology. But they are mainly derived and reworked materials and loads dropped by moving floods. Drifts cover roadsides; fill up areas, concealing the underlying geology. Drifts vary from very thin 


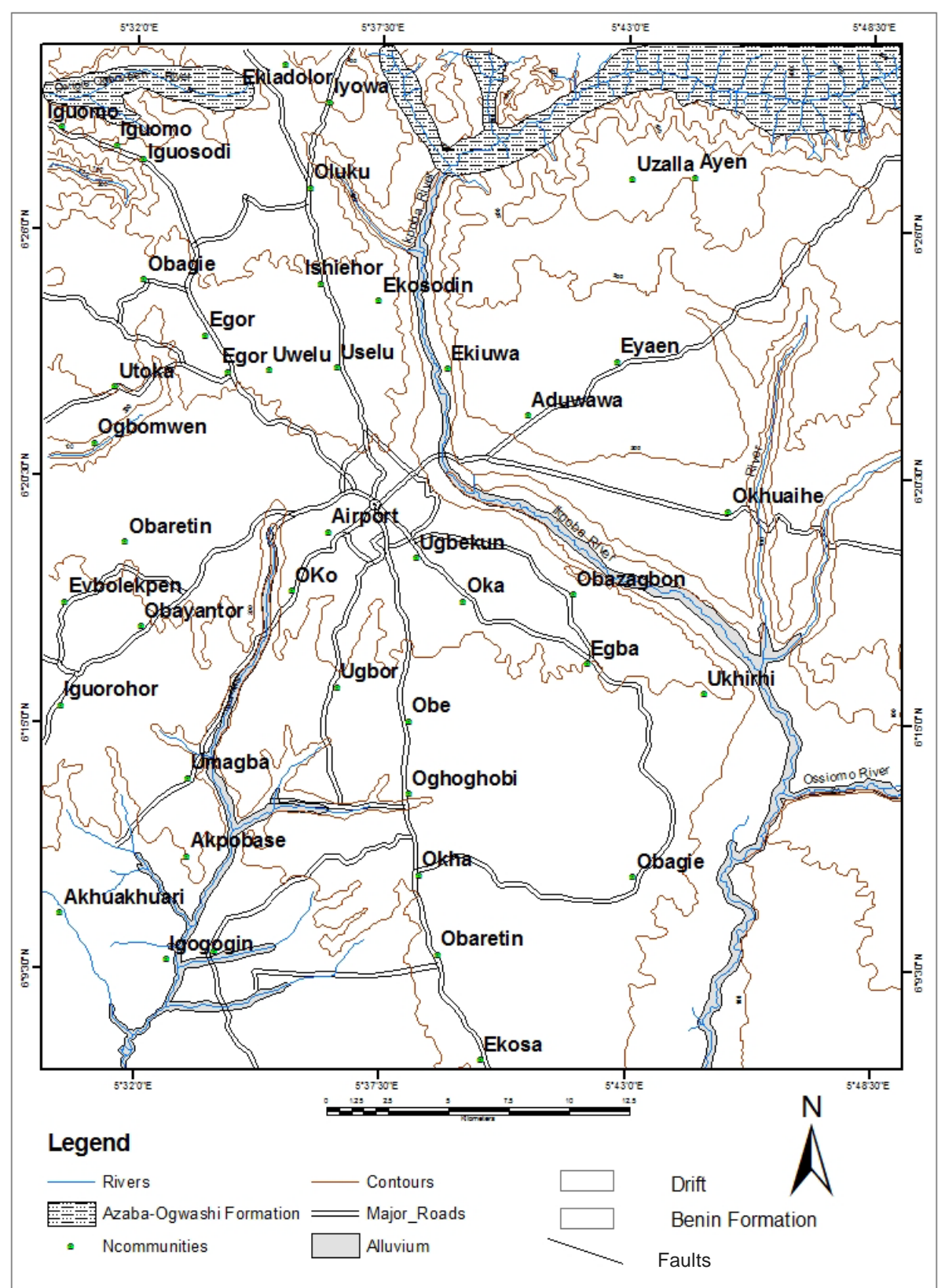

Figure 1. Benin region geological formation (source: Akujieze, 2004).

veneers to up to $0.55 \mathrm{~m}$. The drifts cover about $2 \%$ of the urban area. Where the drifts are stabilized soil profile formation is developed.

\subsubsection{Azagba-Ogwashi (Asaba-Ogwashi) Formation}

The Azagba-Ogwashi formation has been missing spelt as Ogwashi-Asaba formation [6]. It consists of clays, sands and grits and seams of lignite alternating with gritty clays. It grades upwards into the Benin Formation. The Ogwashi-Asaba formation is exposed in stream channels at the northern parts of the Benin Region, west of Ekiadolor-Iwu and $4 \mathrm{~km}$ east of Utekon and north of Azalla, [9].

\section{Methods}

This research was carried out by references to the different works done in the Benin Region. Information was 
obtained from books, journal articles, unpublished thesis and fieldwork observations, measurements and taking photographs of the landscape. Data on the aspects of geology, physiography (relief), and hydrology were gathered from published works. Actual field observations and measurements were carried out on the activities of gully erosion principally. Meteorology information on precipitation and evaporation were gathered from the Federal Ministry of Aviation Department of Meteorological Services (FMAMS), Oshodi, Lagos, Nigeria.

\section{Results and Discussion}

\subsection{Physiography (Relief) and Geomorphology}

Information on the geomorphology of the Benin Region can be found in the works of authors such as [9] [10][16] amongst others. According to these authors, the Benin Region is essentially an area situated in the coastal plains. The region lies in the southern most corner of a dissected margin, a topographical unit which lies north of the Niger Delta, west of the lower Niger Valley and south of the Western plains and ranges [10]. Several parts of the region are surrounded by the Benin historical moats. The region has been described as a tilled plain in the south western direction. The local relief of the region is $91 \mathrm{~m}$ [12] with its highest elevation around Ishan Plateau and Asaba Plateau [11]. [17] applying the Digital Elevation Model (DEM) observed that the highest elevation can be found around the Benin-Auchi Bypass which is about $170 \mathrm{~m}$ (500 feet) above mean sea level approximately. The lowest elevation of $0 \mathrm{~m}$ (0 feet) is found around the Ossiomo, Ikpoba and Ogba floodplains. [13] observed that other than the Ikpoba High which forms an integral part of the Ishan Plateau in the north western corner of the region, the whole of the region is a relatively flat terrain. The areas around Ugbowo, Adolor, Uwasota, Uselu, and Textile Mill Road slope heavily towards the five-junction axis. Much of the western portion of the region is characterized by steep slopes all of them tilling towards Ikpoba River. Much of the western, eastern, central and southern sections of the region is underlain by the Secondary and Tertiary Sedimentary Rock Formation of the Miocene-Pleistocene age referred to as the Benin Formation. The Cretaceous Sedimentary rocks are of the Upper Senonian group and occur mainly around Benin City. The sediments are friable, some very fine and others granular to moderately sorted. They possess an average thickness of $1.2 \mathrm{~cm}$. Benin City lies on the geomorphic unit referred to as the Benin low lands. This is a submission of a regional terrain termed the coastal plain terrace [11]. It is a tilled plain, slopping in the west direction with a general reduction in attitude from the higher plateau landforms of about $1000 \mathrm{~m}$ (350 feet) above sea level in the Ishan Plateau area which is about $70 \mathrm{~km}$ northeast of Benin City.

\subsection{Geomorphological Process}

The geomorphological processes that operate in the Benin Region include deep chemical weathering, slope processes and fluvial activity.

\section{Weathering}

In the tropics, there is a great contrast between the forested lands and the vast rocky surfaces of the savannah and semi-arid lands. The rocky hills which are more or less common in the inter-tropical regions offer ideal conditions for the study of mechanical disintegration of rock mass in situ. Mechanical rock weathering is evidenced by the processes of block and angular disintegration exfoliation basal sapping and pressure release due to unloading [18]. These processes are known to have operated in this region in the early stages of landform development of the region. Evidence of these processes can be found in the accounts of [19] who holds that evidence of deep weathering and progressive stripping of the basal surface exist in Nigeria. The weathering profiles differ considerably as a result of variations in rock structure, differences in the condition of groundwater amongst others. Boreholes records in the Benin Region show evidence of deep chemical weathering overtime. Soil profile reveals that the region is composed mainly of reddish brown sandy laterite. Intermittent layers of porous sands of sandy clays may reach a large depth as found in the borehole drilled in the region. These are products of deep chemical decay of the original parent rock materials. The terrain in Benin City is almost a flat plain with the northern part of the city at a higher elevation of $122 \mathrm{~m}$ - $155 \mathrm{~m}$ (400 - 500 feet). The southern part at lower elevations is of $30 \mathrm{~m} \mathrm{(100} \mathrm{ft)} \mathrm{above} \mathrm{sea} \mathrm{level.} \mathrm{The} \mathrm{Ugbowo-Isiohor-Oluku-Ekiadolor} \mathrm{area} \mathrm{at} \mathrm{the} \mathrm{north-}$ ern fringes of the region constitutes a higher topography than the southern areas of the town occupied by Ogba- 
Ugbor area. The Ikpoba river valley constitutes a topographic depression across the region in a north-east and south-east direction. This segments the town into sections viz: the eastern "Ikpoba Hill" sector and the "Western sector" sector, on which most of the town rests (Figure 2). Within the western sector prominent physiographic reddish earth levees encompass the region in a concentric outline. This marks out the edge of the historical ancient Benin meat which was used as an outer defensive perimeter of the ancient Benin kingdom. It is a cultural artifact.

\subsection{Drainage}

Three river systems drain the Benin Region. They are the Ikpoba River, the Ogba River and Owigie-Ogbovben River systems. They are small in size being $(1-5 \mathrm{~m})$ wide and $(0.5-3.0 \mathrm{~m})$ deep [9]. The major one is the Ikpoba River. Its' headstream originates from the N.E outside the Benin Region and flows east to west across the northern quarter of the region and then swings south and south east. This change in direction indicates some structural control. There is a prominent artificial man-made lake referred to as the Ikpoba Lake along its course in Okhoro. The lake is about $1 \mathrm{~km}^{2}$ in area and is used mainly for municipal water supply for drinking, fishing
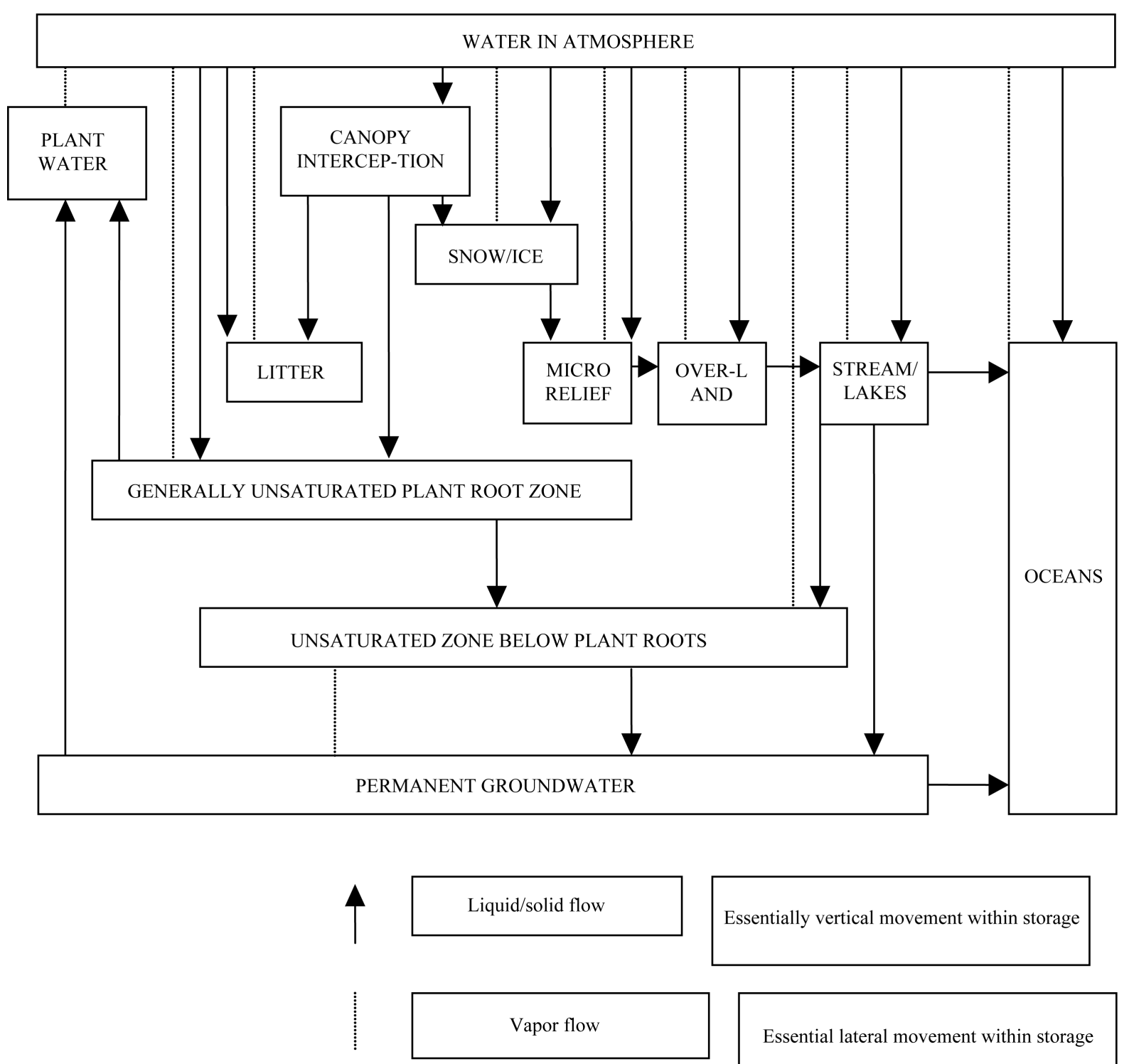

Essentially vertical movement within storage

Essential lateral movement within storage 
and recreation. The south western part of the Region is drained by the Ogba River Basin. The head of the stream originates from Oko-Ugbor environment. The three rivers constitute a dendrite drainage pattern. The drainage density can be described as lower sparse.

\subsubsection{Surface Water Hydrology}

[20] stated that water is the elixir of life, without it life is not possible/the Benin region has an ambious quantity of surface water substrate geology and groundwater inter-connections.

\subsubsection{The Hydrological Cycle and Processes}

Hydrology is the inter-disciplinary science that deals with all waters of the earth, including their origin, occurrence, circulation and distribution on and in the earth, their chemical and physical properties, and their reactions with their environment, including their relations with living things. The scope of hydrology, therefore, encompasses the full history and behaviours of water in the earth system. Hydrology is defined as the science of the water of the earth, its distribution, composition and movement. It can also be defined as the science of the earth's water and its motions through the hydrological cycle [21] [22]. Below is the schematic diagram of the hydrological cycle or system to show various component of storage and fluxes of flows

The hydrological (water) cycle is defined as... "the ceaseless movement of water by evaporation into the atmosphere; by mass transportation as a vapour component of the atmosphere: by precipitation on land and sea: by movement into the ground to become soil moisture and groundwater; by runoff in rivers from land to sea: by discharge of groundwater to rivers and lakes and directly to the sea from glaciers and ice caps [22].”

[22]-[25] worked on and developed basic water budget equations from which water estimates could be made. A general hydrologic balance equation is given as

$$
\mathrm{P}=\mathrm{I}+\mathrm{R}+\mathrm{E}
$$

where $\mathrm{P}=$ Precipitation (mm), I = Infiltration (mm), R =Runoff (mm) and E = Evapotranspiration (mm). Many versions of the equation have been developed to facilitate water budgetary studies.

\subsubsection{Precipitation}

In the Benin Region, the precipitation is mainly rainfall. Precipitation refers to the various liquids and frozen forms of water like drizzle, rain, snow, dew, hoarfrost, fog-drip and rime. Only rain makes significant contribution to precipitation totals and in the tropics, where rainfall is used interchangeably with precipitation [26]. A full description of the spatial and seasonal pattern of rainfall of the region can be found in the numerous works of [27]-[29] amongst others.

\subsubsection{Evapotranspiration}

In Benin Region, Evapotranspiration is highest in January-March with a value ranging from 150 - 180 mm. The lowest occurs in June-August with a record of $50 \mathrm{~mm}$ - $80 \mathrm{~mm}$. [9] observed that both 5 year and 8 year mean annual total values of Evaporation using Class A-Pan method in Benin Region are $1460 \mathrm{~mm}$ and $1420 \mathrm{~mm}$ respectively. The values are compactible and constitute $66 \%$ of the total annual precipitation. See also [30].

\subsection{Runoff}

Runoff includes all the water flowing in the stream channel, past any given section [31]. Sources of water in the stream channels include precipitation or direct rain into the streams, surface runoff, that is, water from precipitation or rain fall on the ground surface that finds its way to the stream channels without first infiltrating into the soil. This percolates down to the water table to join the ground water flow (baseflow) which originates from precipitation. This then infiltrates through the soil and percolates to the water table to join the ground water system. It stays here for some days, weeks, months or years before finding its way through the aquifer into the stream channels. Urbanization can contribute to runoff (and discharge) through sewers, imported water, wastes and effluent discharges. Three water bodies and sub-basin exist in the Benin Region viz:

1) The Ikpoba River Okhuaehe River system drains north to southern parts of the region. The measured discharged at Ikpoba bridge drains an estimated area of $722 \mathrm{~km}^{2}$ mostly north of the Benin region [9].

2) The Ogba River system drains southwest of the region.

3) The Owigie-Ogbovben River System drains the north west of the region. 
The Ikpoba and Ogba rivers are tributaries of Ossioma River and both dischange their flow into Ossiomo River in the southern portion of the region (Figure 3).

\subsubsection{The Ikpoba River System}

The Ikpoba River takes it source from an extension of the western highland in the north and northeast of the region. It flows from an east to west direction, then meanders at Utekon to flow southwards with Ekosodon, Ugbowo, Okhoro and New Benin to the eastern bank. It crosses Temboga and winds again to flow southeast after Ikpoba-Hill where it is bridged along Benin-Agbor road. It flows towards the Ikpoba Okha LGA in the region. It is a perennial stream flowing throughout the year. At the northern region the Ikpoba River is high above the water table and as such contributes an influent flow into the aquifer while in the southern reaches, the river receives groundwater from the water table aquifer and thus, become effluent flow [9]. The width of the river varies from $5-11 \mathrm{~m}$ and has a depth of $3-8 \mathrm{~m}$. It flows for a distance of $48 \mathrm{~km}$ across its sub-drainage catchment basin estimated at $722 \mathrm{~km}^{2}$ and about $330 \mathrm{~km}^{2}$ of this area is within the Benin City urban i.e. $46 \%$ of the entire Ikpoba drainage basin. The Ikpoba River lake reservoir is about $2.15-3 \mathrm{~km}$ long and $320 \mathrm{~m}$ wide impounding an area of $1.5 \times 10^{6} \mathrm{~m}^{3}$ of water within an area of $1.1 \times 10^{6} \mathrm{~m}^{3}$ with a spill rate of $312 \mathrm{~m}^{3} \cdot \mathrm{sec}^{-1}$ [9]. The Ikpoba River dam was commissioned in 1987.

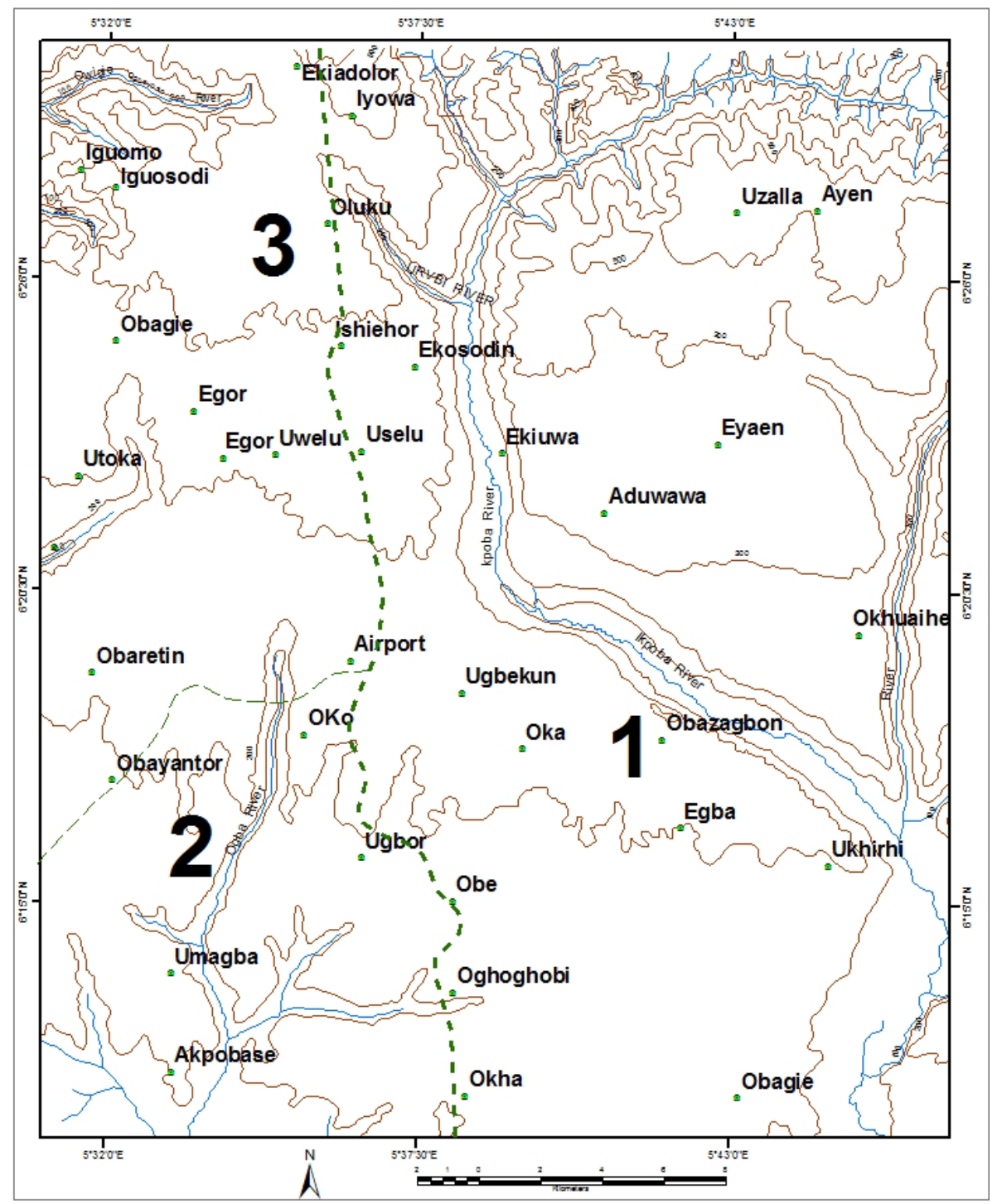

Figure 3. Benin region sub-basins (source: Akujieze, 2004). 


\subsubsection{The Ogba River System}

The Ogba River rose from the highland area in Ekehuan-Ugbiyokho area of the region. It flows southwest for about $12 \mathrm{~km}$ as a sub-tributary of the Ossiomo River. The width is $1-3 \mathrm{~m}$ and depth is $1-2 \mathrm{~m}$. The area is estimated at $40 \mathrm{~km}^{2}$. The Ogba River receives effluent flows from the groundwater storage.

\subsubsection{The Onigie-Ogbovben River System}

This river drains the northwestern portion of the basin. It flows west and is perennial. Its sub-catchment area is estimated to be $10 \mathrm{~km}^{2}$.

\subsection{Discharge in Benin Region}

\section{Ikpoba River Discharges}

The mean annual discharge of Ikpoba River for 1982-1983 and 1993-2002 was $1411 \mathrm{~mm} / \mathrm{yr}$, which is $1.019 \times$ $10^{9} \mathrm{~m}^{3}$ with a mean annual baseflow of $1256.23 \mathrm{~mm}\left(0.907 \times 10^{9} \mathrm{~m}^{3}\right)$. This constitutes $87.65 \%$ of the total flow. It has a mean annual surface runoff of $225.18 \mathrm{~mm}\left(0.112 \times 10^{9} \mathrm{~m}^{3}\right)$ or $24.4 \%$ of the total discharge [9].

\subsection{Water Resources}

In general, the water resources of any area are sub-divided into two broad groups. Ikhile (2007a) reviews them to include:

1) Surface Sources: These include streams, springs, ponds, lakes and all other natural bodies of water occurring in earth's surface flowing or stagnant. These have been discussed fully under general hydrology.

2) Underground Sources: In discussing the water resources, the ultimate source of water found on the earth's surface is found to be precipitation in the form of rainfall over the area. Of the rain that falls, some percolate to replenish the underground waters, some runoff to join streams and rivers [32] [33]. The sub-basins of the Benin Region contain those north-south flowing rivers discharging eventually into the western lagoons. The rivers originate in the northern plateau with annual rainfall of 1200 to $1500 \mathrm{~mm}$, whereas the annual rainfall over the lagoons varies from 1500 - $2000 \mathrm{~mm}$. Continuous discharge measurements are seldom available in the region. The potential surface water resources are estimated mostly by applying areal rainfall, and runoff coefficients in consideration of topographical conditions of the river basins. The runoff yield is estimated at 150 to $200 \mathrm{~mm}$ in the sub-basins of the region [34]. However, [9] holds that the total potential surface water resources may amount to $350 \mathrm{~mm}$ for the total catchment area.

\subsection{Erosion in the Region}

[35] has shown the degree of Erosion in the region. It is observed that not less than twelve major erosion sites can be identified in the region. These include

1) University of Benin, from the Capitol to Block of Flats to Ikpoba River;

2) Queen Ede Secondary School and Environ;

3) Queen Ede College Road, Oregbeni;

4) 2nd /7th Street, EDPA Housing Estate, Oregbeni;

5) Costain Road and Environ;

6) Virginia Street and Environs;

7) Moat Behind Edo College (Irhirhin Quarters);

8) Teboga Road (Sand Mining);

9) Okokhuo and Environs;

10) Supply and Transport (S\&T) Road;

11) Agbonmoba/Osunde Street and Environ;

12) Urhonigbe Town and Environs. Some of these are shown in Figure 4 to Figure 6. The satellite imageries show the whole areas covered by gullies in these sites, while Figure 6 is a typical gully site at the University of Benin.

\section{Control Measures}

Control measures of the menace of gully erosion in the region are on-going. The National Erosion and Watershed Management Project (NEWMAP) with assistance from the World Bank has awarded contracts for Flood 

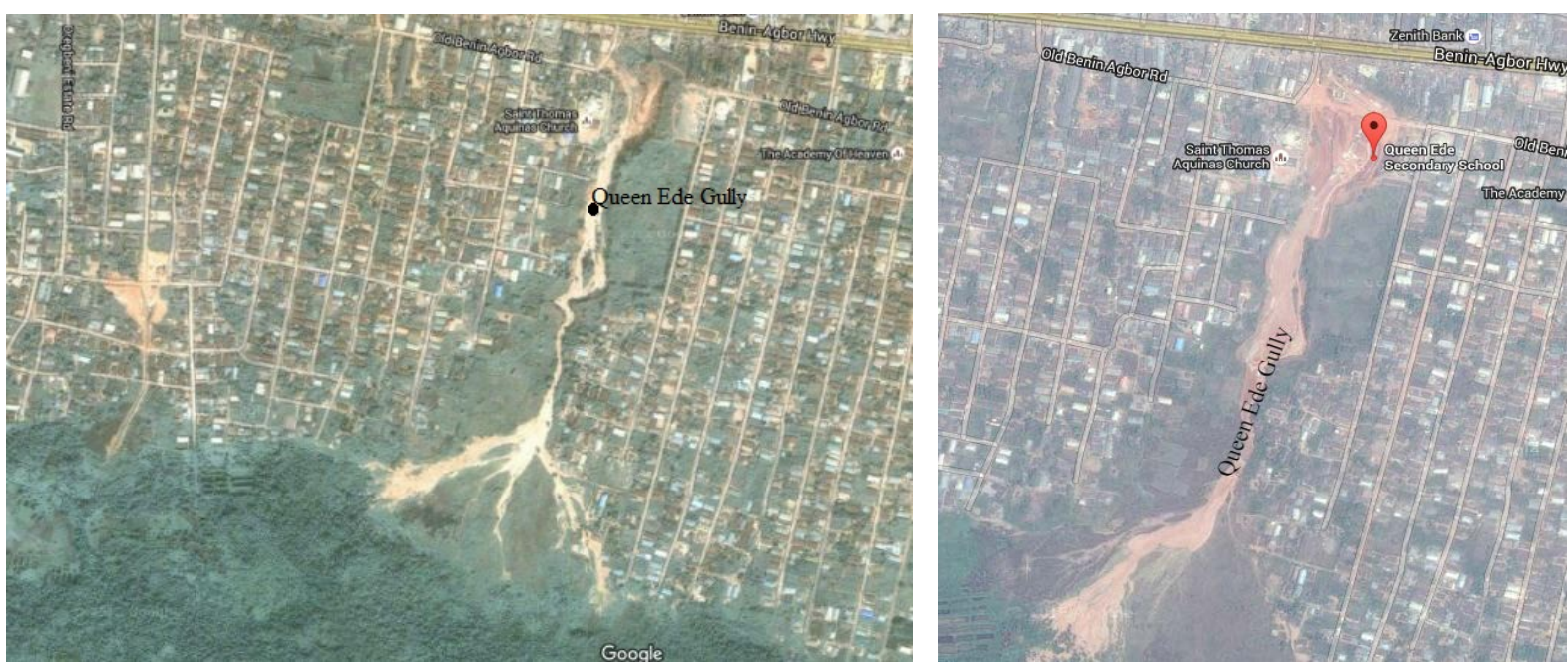

Figure 4. Satellite imagery of Queen Ede gully erosion site.
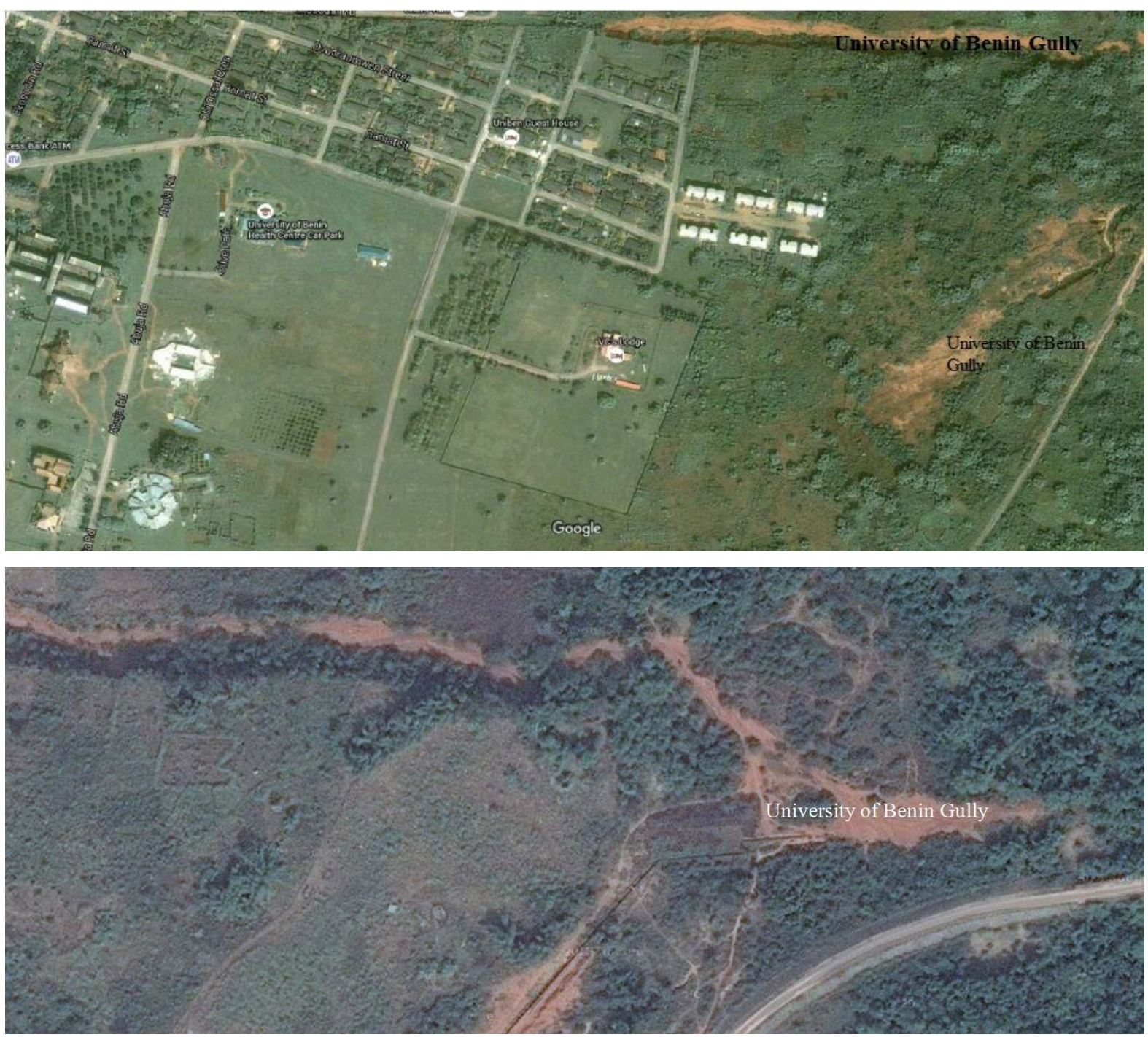

Figure 5. Satellite imagery of university of Benin gully site. 

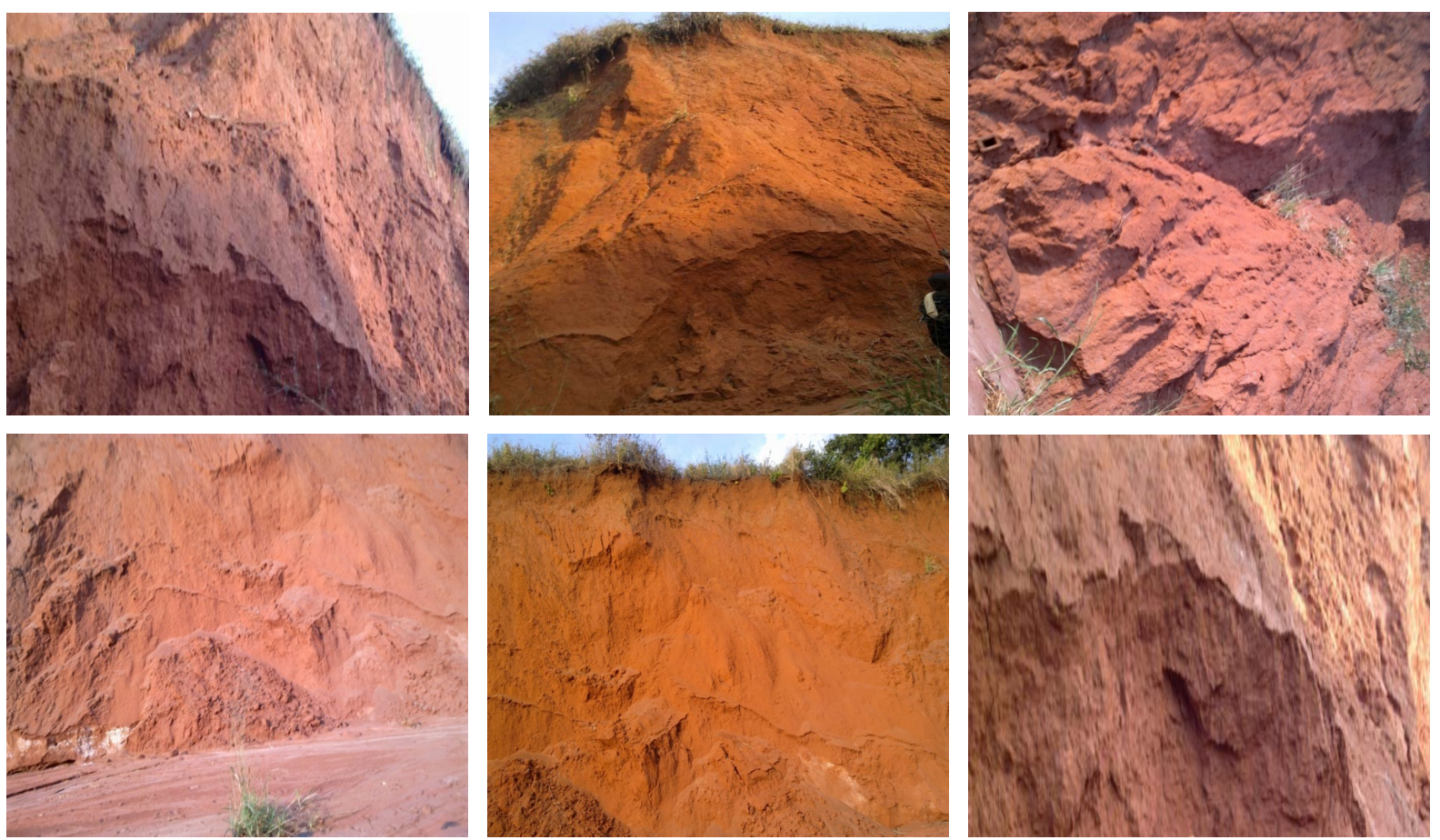

Figure 6. Gully erosion sites, university of Benin.

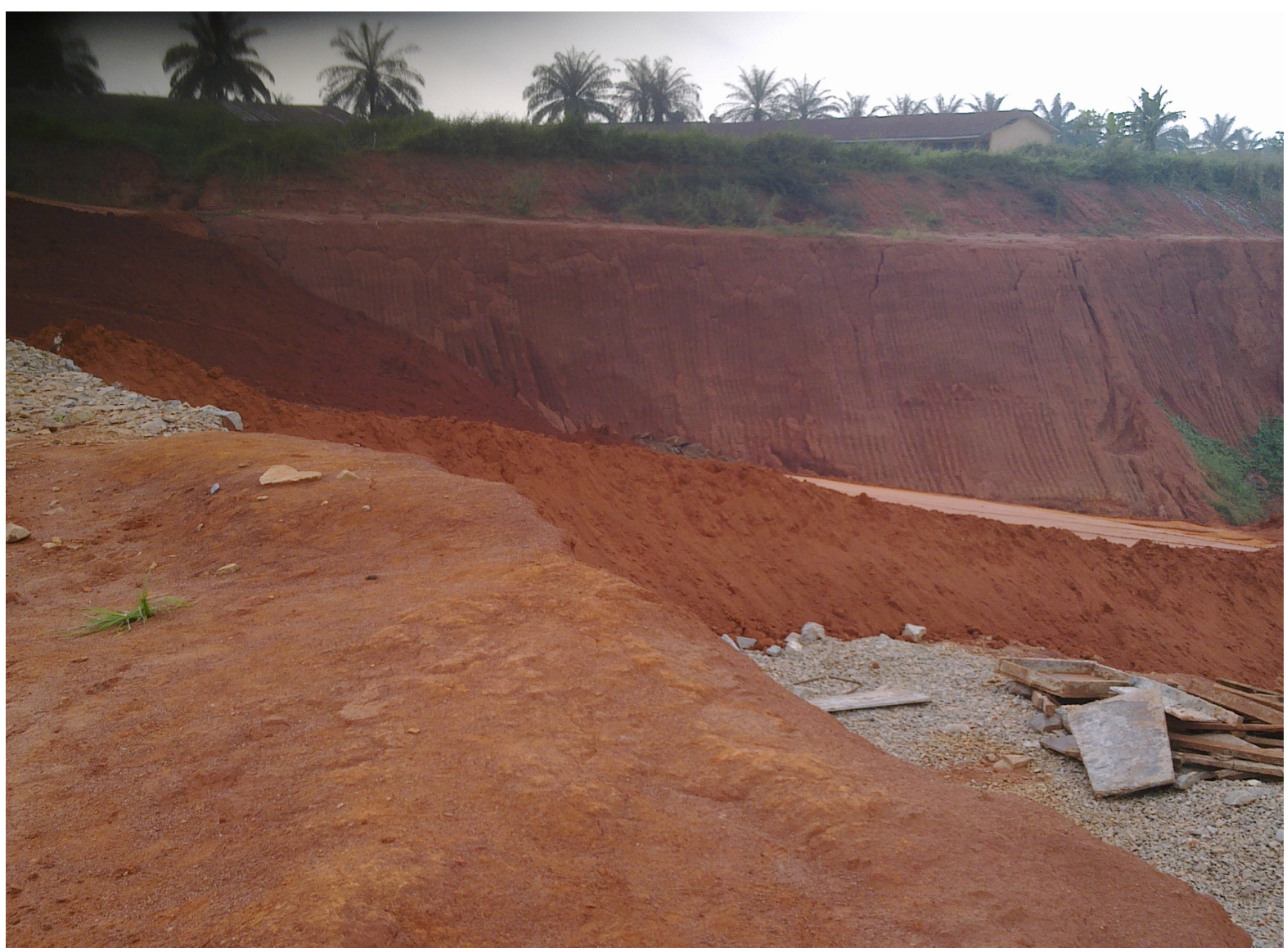

Figure 7. Erosion control works at Queen Ede in Benin region. 

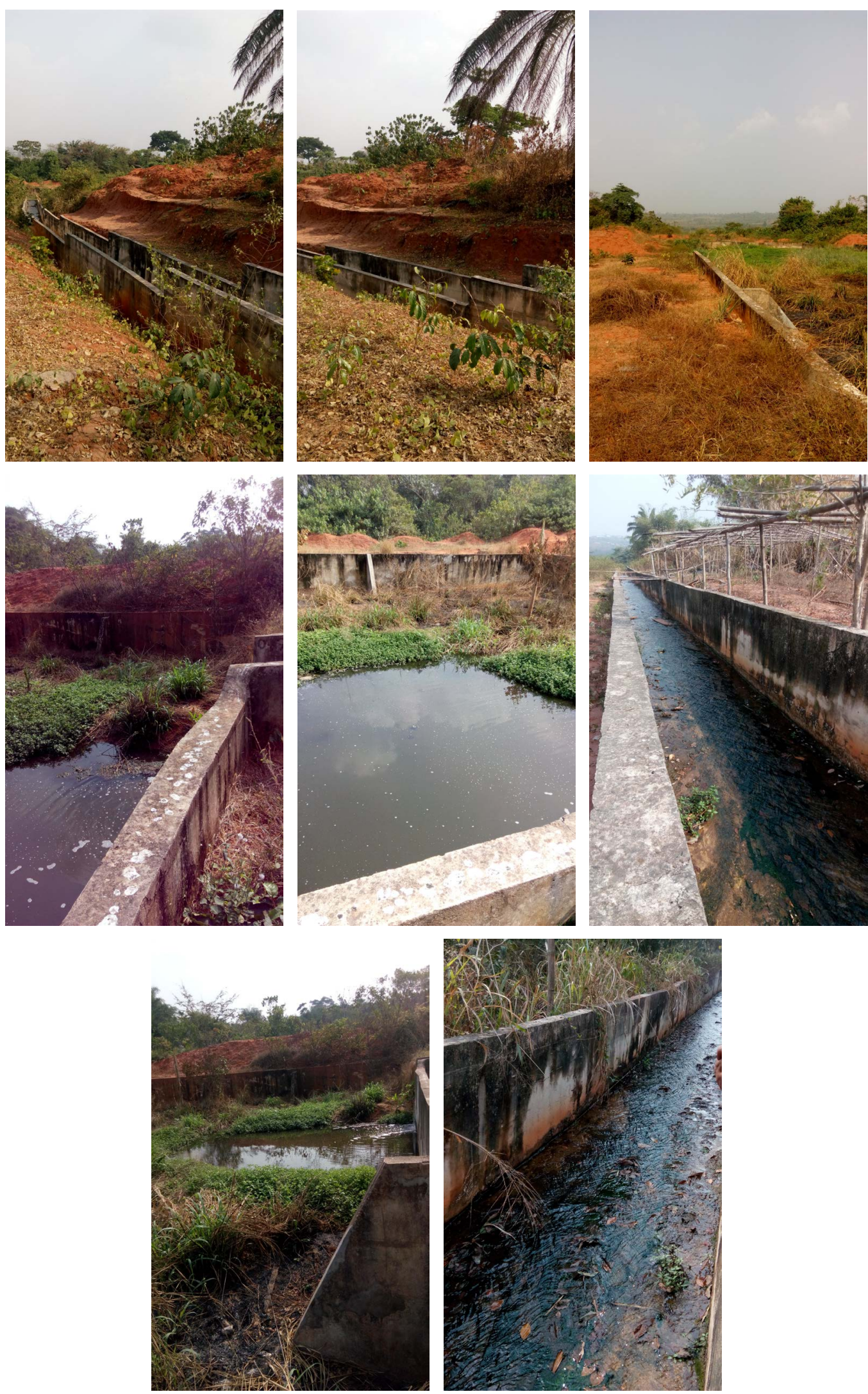

Figure 8. Erosion control works at University of Benin. 

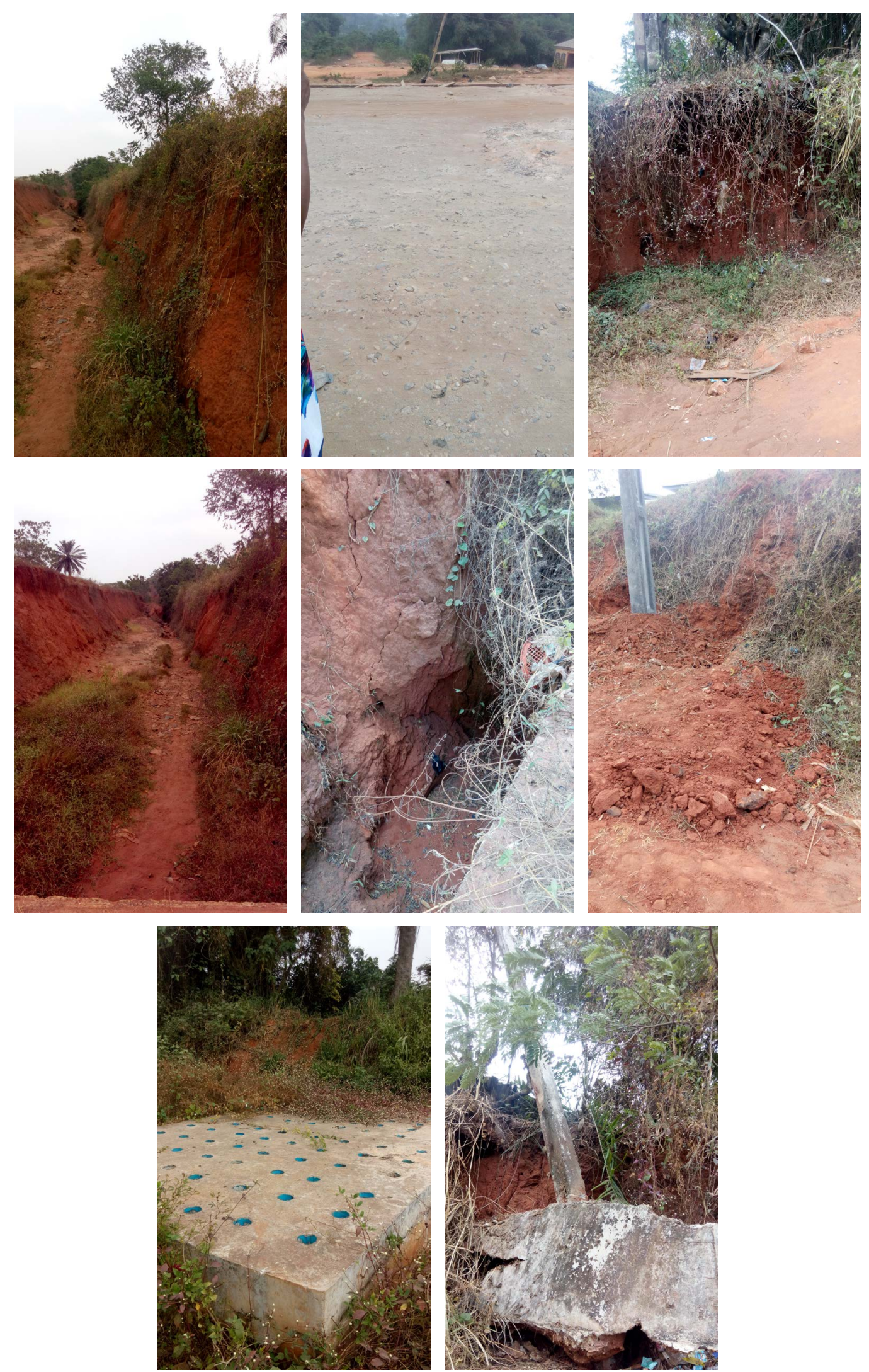

Figure 9. Erosion control works at Asoro. 
and Erosion Control in Queen Ede and Ekehuan road gully erosion sites in the region. A South African based company Aurecon Group has also been commissioned by NEWMAP (Edo State) to carry out study and design for Ogiso/Osunde and Edo College gully erosion sites as well as Gapiona Watershed Flood Control Project. These designs have since been completed and submitted to NEWMAP for approval and implementation under the World Bank Assisted Programme. A typical Gully Erosion Control works at Queen Ede is shown in Figure 7. Other Gully Erosion Control Works are shown on Figure 8 and Figure 9 for University of Benin and Asoro respectively.

\section{Conclusion}

The geomorphology and hydrology of the Benin Region has been discussed. This region has not been documented by researchers working on landforms of Nigeria. The region is underlain by the sedimentary formation of the South sedimentary basin. The geology is generally marked by top reddish earth, composed of ferruginized or literalized clay sand. Geologically, the Benin Region comprises of 1) the Benin formation; 2) alluvium; 3) drift/top soil and 4) Azagba-Ogwashi (Asuba-Ogwashi). The main water sources are surface water and underground water. The people rely majorly on borehole water through individual efforts. The landscape of the region has been subjected greatly to land degradation in the form of erosion and flooding. It is a region under serious environmental degradation requiring continuous Government Intervention.

\section{References}

[1] Faniran, A. (1972) Depth and Pattern of Weathering in the Nigerian Pre-Cambrian Basement Complex Rock Area. African Geology, University of Ibadan.

[2] Thomas, M.F. (1974) Tropical Geomorphology. Macmillan, London.

[3] Faniran, A. and Jeje, L.K. (1983) Humid Tropical Geomorphology. Longman Groups Ltd., Ibadan.

[4] Parkinson, J.A. (1907) The Post Cretaceous Stratigraphy of Southern Nigeria. Quaternary Journal of Geological Society, 63, 311-320.

[5] Tattam, C.M. (1943) A Review of Nigerian Stratigraphy. Research and Educational Development of the Geological Survey of Nigeria, 26-27.

[6] Reyment, R.A. (1965) Aspects of the Geology of Nigeria. Ibadan University Press, Ibadan.

[7] Short, K.C. and Stauble, A.J. (1967) Outline of the Geology of Onitsha, Owerri and Benue Provinces. Geological Survey of Nigeria, Bulletin No. 21.

[8] Whiteman, A.J. (1982) Nigeria: Its Petroleum Geology, Resources and Potential, 1 \& 2. Graham and Trtman Ltd., London, 26-110.

[9] Akujieze, C.N. (2004) Effects of Anthropogenic Activities (Sand Quarrying and Waste Disposal) on Urban Groundwater System and Aquifer Vulnerability Assessment in Benin City, Edo State, Nigeria. PhD Thesis, University of Benin, Benin City, Nigeria.

[10] Fetter, C.W. (1994) Applied Hydrology. 3rd Edition, Prentice Hall Englwood Cliff, NJ, 07632.

[11] Buchana, K.M. and Pugh, J.C. (1955) Lands and Peoples in Nigeria. University of London Press, London.

[12] Udo, R.K. (1970) Geographical Regions of Nigeria. Heinemann Educational Books, London.

[13] Odemerho, F.O. (1988) Benin City: A Case Study of Urban Flood Problem. In: Sada, P.O. and Odemerho, F.O., Eds., Environmental Issues and Managements in Nigerian Development, Evans Brothers, Ibadan, 97-106.

[14] Omiunu, F.G.I. (1988) Flood and Traffic Management in Benin City. In: Sada, P.O. and Odemerho, F.O., Eds., Environmental Issues and Management in Nigerian Development, Evans Brothers, Ibadan.

[15] Olaye, D. (2004) Geomorphological Hazards: The Impact of Flooding in Benin-City. A Case Study of Adolor, Uselu and 5-Junction. B.Sc. Thesis, University of Benin, Benin City.

[16] Iseghosimhe, O.M. (2005) Assessment of Land Degradation. A Case Study of Ekosodin Community in Ovia North-East LGA, Edo State, Nigeria. B.Sc. Thesis, University of Benin, Benin City.

[17] Ikhile, C.I. and Oyebande, L. (2007) Application of Geographic Information System GIS to the Study of Landuse Changes in the Osse-Ossiomo River Basin, Edo State. IAHS Publications No. 316, 245-251.

[18] Aghughu, C.I. (1981) The Phenomenon of Weathering at the Permanent Site of the University of Jos. B.Sc Thesis, University of Jos, Jos.

[19] Thomas, M.F. (1966) Some Geomorphological Implications of Deep Weathering Pattern of Crystalline Rock in Nige- 
ria. Transactions of the Institute of British Geographers, No. 40, 173-193. http://dx.doi.org/10.2307/621576

[20] Strahler, A.N. and Strahler, J.A. (1978) Environmental Geoscience. John Wiley \& Sons, London.

[21] Oyebande, L. (1998) The Water Cycle: Courier of Health and Wealth, How Sustainable Is It? Inaugural Lecture Series, University of Lagos Press, Lagos.

[22] Meinzer, O.E. (1942) Hydrology. McGraw-Hill Book Company, New York.

[23] Budyko, M.I. (1956) Teplovoy Balans, Zmnoy Poverkhnosti (Heat Budget of the Earths Surface). Gidrometeoizdat, Leningra.

[24] Chow, V.T. (1964) Handbook of Applied Hydrology. McGraw-Hill Book Company, New York.

[25] Ayoade, J.O. (1988) Introduction to Climatology for the Tropics. Spectrum Books Ltd., Ibadan. http://dx.doi.org/10.1144/GSL.JGS.1907.063.01-04.19

[26] Ikhile, C.I. and Ikhile, G.U. (2003) Effects of Climate Change on Irrigation Activities: A Case Study of the Benin-Owena River Basin Irrigation Projects. IAHS Publications No. 281, 287-293.

[27] Ikhile, C.I. (2007) Impacts of Climate Variability and Change on the Hydrology and Water Resources of the Benin-Owena River Basin. PhD Thesis, University of Benin, Benin City.

[28] Ikhile, C.I. (2012) The Concept of Climate Change and Water Resources Issues in Benin-Owena River Basin, Nigeria. NMetS Book on Climate Change, Climate Variability and Change: Saving our Tomorrow Today (in Press).

[29] Ikhile, C.I. and Aifesehi, P.E.E. (2013) Rainfall Variability and Extreme Climate Change Impacts in Sections of the Benin-Owena River Basin, Nigeria. Nigerian Journal of Hydro Logical Sciences, 2, 110-126.

[30] Ikhile, C.I. and Olorode, D.O. (2012) Climate Change and Water Balance in the Osse-Ossiomo Sub-Basin of S.W. Nigeria. Port Harcourt Journal of Social Sciences, 3, 98-109.

[31] Wisler, C.O. and Brater, E.F. (1959) Hydrology. 2nd Edition, John Wiley \& Sons Inc., New York.

[32] Okodugha, A.I. (1977) Surface and Subsurface Water Supply in Auchi Area. B.Sc. Thesis, University of Benin, Benin City.

[33] Ikhile, C.I. (1990) An Assessment of Surface Water Quality in Orle River Basin. M.Sc. Thesis, University of Benin, Benin City.

[34] Sanyu, R.O. and Sumiko, A.P. (1994) Draft Report on Study of the National Water Resources Master Plan. Federal Ministry of Water Resources Rural Development (FMWRRD), Abuja.

[35] Ikhile, C.I. (2015) Digital Terrain Modelling of the Osse-Ossiomo Sub-Basin of the Benin-Owena River Basin. Ghana Journal of Geography, Unpublished. 